(C) 2014

\author{
Локес-Крупка Т. П., аспірант
}

(науковий керівник - доктор біологічних наук, професор, академік НААН М. І. Цвіліховський)

Національний університет біоресурсів і природокористування України

\title{
ХАРАКТЕРНІ КЛІНІЧНІ ОЗНАКИ У СВІЙСЬКИХ КОТІВ ЗА ГЕПАТОЛІПІДОЗУ
}

\section{Рецензент - кандидат ветеринарних наук Н. С. Щербакова}

Більшість захворювань печінки у свійських котів мають спільну клінічну картину, але кожному з них притаманні свої особливості прояву. У статті наведено клінічні ознаки гепатоліпідозу у свійських котів: іктеричність кон'юнктиви, слизової оболонки ротової порожнини, носа та шкіри, наявність блювання, погіршення якості шерсті та свербіж. Встановлено, щчо ожиріння тварин, з наступним проявом анорексї, є сприятливим фактором розвитку ліпідозу печінки. Наведена вікова та порідна схильність свійських котів до захворювання на гепатоліпідоз.

Ключові слова: коти, печінка, гепатоліпідоз, клінічні ознаки, симптом.

Постановка проблеми. У сучасному світі спостерігається тенденція до утримання власниками свійських котів різних порід, які потребують великої уваги та догляду. Порушення умов годівлі та утримання цих тварин призводить до розвитку різноманітної внутрішньої патології, особливо хвороб печінки. Більшість захворювань печінки у свійських котів мають спільну клінічну картину, але кожному з них притаманні свої характерні особливості прояву.

Так, гострий гепатит, крім іктеричності кон'юнктиви проявляється значною інтоксикацією організму, цироз - часто супроводжується асцитом тощо. Таким чином встановлення характерної клінічної картини за гепатоліпідозу в свійських котів може скорегувати дії лікаря ветеринарної медицини у необхідному напрямку для подальшого вибору додаткових методів дослідження та встановлення лікування.

Аналіз основних досліджень і публікацій, в яких започатковано розв'язання проблеми. За даними Р. Кірка [9], у свійських котів ліпідоз реєструють у $49 \%$ випадків, тоді як запальні захворювання печінки складають $26 \%$, а лімфосаркома $-7 \%$ випадків.

Гепатоліпідоз вважається первинним, ідіопатичним захворюванням у багатьох котів, але при зборі анамнезу в більшості випадків виявляють обставини, або захворювання, які супроводжується відсутністю апетиту [1].

Найчастіше супутніми патологіями за гепатоліпідозу у свійських котів є діабет, нефропатії, панкреатит, копростаз та хвороби ротової порожнини. V. Biourge із співавторами [12] підтвердили, що тривале голодування, за наявності ожиріння, може викликати клінічний прояв гепатоліпідозу в котів. Характерні клінічні прояви та зміни біохімічних показників спостерігали вже після кількох тижнів добровільної відмови тварин від корму. Дані ознаки проявляються внаслідок втрати 30-35 \% маси тіла.

Метою досліджень було встановлення характерних клінічних ознак гепатоліпідозу у свійських котів.

Завдання: дослідити клінічні ознаки свійських котів, хворих на гепатоліпідоз, і виявити характерні риси.

Матеріали і методи дослідження. Об'єктом дослідження були 47 свійських котів різної статі, віком від 2-х до 13-ти років хворих на гепатоліпідоз. Коти без видимих ознак патології печінки (n=10) увійшли у контрольну групу.

Усі тварини були обстежені за загальноприйнятою схемою.

Результати досліджень. За результатами досліджень були встановлені основні загальноклінічні ознаки гепатоліпідозу в свійських котів (табл. 1.).

У більшості тварин відмічали пригнічення загального стану $(89,4 \%)$. Внаслідок порушення обміну речовин або первинної хвороби у тварин погіршувався або повністю зникав апетит, спостерігали часте блювання. Це призводило до різкого схуднення тварини (рис. 1).

У 76,6\% хворих котів спостерігали іктеричність кон'юнктиви, слизової оболонки ротової порожнини, носа та непігментованих ділянок шкіри (рис. 2). Це було найбільш характерним симптомом для всіх захворювань печінки.

Іктерус, також відомий як жовтяниця, загальноклінічний розлад у тварин, що проявляється за надлишку відкладення в тканинах білірубіну. Нормальний вміст білірубіну в сироватці крові котів, за даними авторів, складає менше, ніж 17,0 ммоль/л [8], хоча багато українських дослідників вважають верхньою межею цього показника 12,0 ммоль/л. 
СТОРІНКА МОЛОДОГО ВЧЕНОГО

\section{1. Показники клінічного стану хворих на гепатоліпідоз свійських котів}

\begin{tabular}{|c|c|c|}
\hline \multirow{2}{*}{ Клінічні ознаки } & \multicolumn{2}{|c|}{ Хворі коти $(\mathrm{n}=47)$} \\
\cline { 2 - 3 } & кількість & $\%$ \\
\hline Гіпорексія & 45 & 95,7 \\
\hline Пригнічення & 42 & 89,4 \\
\hline Іктеричність кон'юнктиви & 36 & 76,6 \\
\hline Свербіж & 31 & 66,0 \\
\hline Наявність лупи & 31 & 66,0 \\
\hline Ожиріння & 28 & 59,6 \\
\hline Різке схуднення & 28 & 59,6 \\
\hline Болючість печінки & 26 & 55,3 \\
\hline Блювання & 23 & 48,9 \\
\hline
\end{tabular}

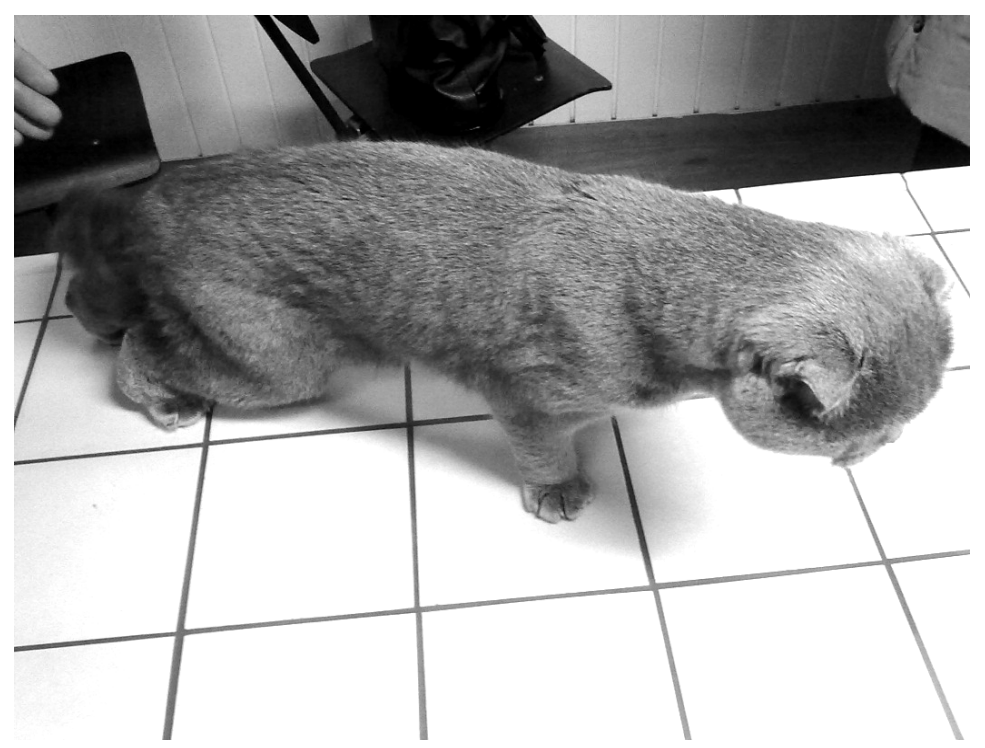

Рис. 1. Загальний вигляд кота, хворого на гепатоліпідоз, значне схуднення. Кіт, британської породи, вік 8 років

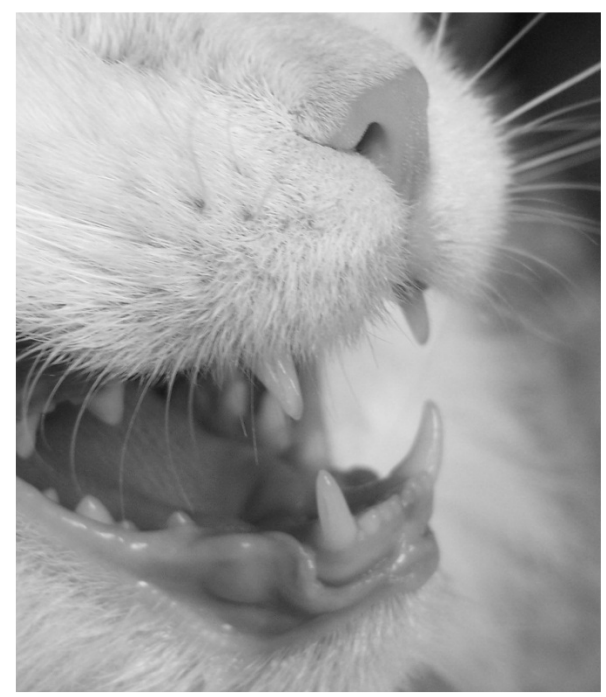

Рис. 2. Іктеричність слизової оболонки ротової порожнини кота 


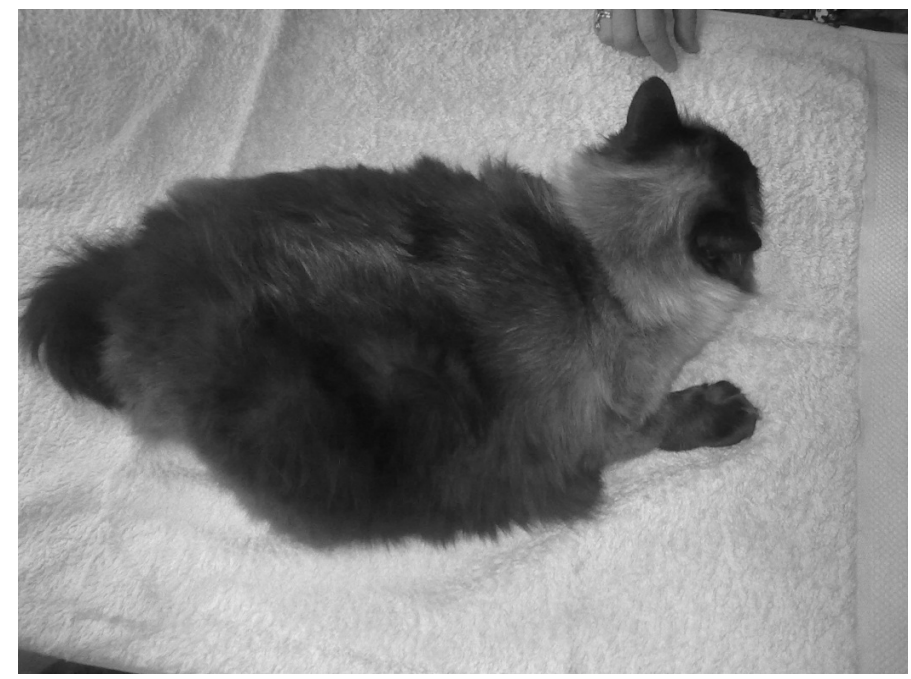

Рис. 3. Загальний вигляд кота, хворого на гепатоліпідоз, значне ожиріння. Кішка метис, вік 7 років

Серед дослідників існує думка, що жовтяниця розвивається тоді, коли рівень білірубіну сягає вище 25,0-35,0 ммоль/л [9]. Літературні дані щодо вмісту білірубіну досить суперечливі, але всі вони мають спільну думку, жовтяничність слизових оболонок першочергово розвивається за підвищення вмісту прямого білірубіну, тобто внаслідок набування ним водорозчинної форми.

За ліпідозу печінки у 59,6\% свійських котів відмічали ожиріння (рис 3), що є сприятливим фактором розвитку гепаліпідозу.

Більше, ніж у половини хворих домашніх котів спостерігали зміну стану шерстного покриву. У них відмічали скуйовдження шерсті, наявність лупи та свербіж. Такі зміни проявлялися внаслідок подразнюючої дії жовчних кислот на чутливі рецептори шкіри.

Провівши аналіз статевої залежності захворюваності на гепатоліпідоз нами було встановлено фактично однакову схильність самиць та самців до цієї хвороби (табл. 2).

Базуючись на дані вікової динаміки гепатолі- підозу можна свідчити, що свійські коти віком до 2-х років не схильні до даного захворювання внаслідок необхідності часового фактору в патогенезі хвороби.

Найбільш часто дана патологія реєструється у стерилізованих свійських котів середнього віку, як наслідок гормональних змін, що призводять до ожиріння тварини та є сприятливим фактором розвитку гепатоліпідозу.

Наші результати в основному співпадають 3 даними ретроспективних досліджень серед котів старше двох років, що вказують на деяке переважання даної патології в самиць (48 з 77 (62\%)) [10]. Провівши аналіз порідної схильності до захворювання на гепатоліпідоз нами виявлено, що найчастіше дане захворювання спостерігається у свійських котів британської та європейської короткошерстої порід, а саме в 31,9 та 29,8\% випадків, відповідно.

Існує ймовірність такої частоти захворюваності саме цих порід у відповідності з сучасними тенденціями щодо їх утримання.

\section{2. Статева та вікова схильність свійських котів до захворювання на гепатоліпідоз}

\begin{tabular}{|c|c|c|c|c|}
\hline \multirow{2}{*}{ Вік } & \multicolumn{2}{|c|}{ Самиці } & \multicolumn{2}{c|}{ Самці } \\
\cline { 2 - 5 } & стерилізовані & нестерилізовані & кастровані & \multirow{2}{*}{ некастровані } \\
\hline До 2-х років & - & - & - & - \\
\hline $2-6$ & 3 & 1 & 4 & 6 \\
\hline $7-10$ років & 8 & 5 & 6 & 3 \\
\hline Старше 10 років & 5 & 3 & 3 & 9 \\
\hline Усього: & 16 & 9 & 13 & - \\
\hline
\end{tabular}




\section{СТОРІНКА МОЛОДОГО ВЧЕНОГО}

Із 47-ми випадків хворих тварин десять випадків припадало на котів перської породи, а 7 тварин були метисами.

Був зареєстрований один випадок захворюваності на гепатоліпідоз у кішки породи сфінкс. Цей випадок є більше виключенням, ніж правилом для даної породи.

Висновки: 1. Основними клінічними проявами гепатоліпідозу в свійських котів $є$ іктеричність кон'юнктиви та видимих слизових оболонок, часте блювання, відмова від корму, погір-

\section{БІБЛІОГРАФІЯ}

1. Тирсіна B. I. Гепатопатії: гострі та хронічні / В. I. Тирсіна // Практична медицина. - 1999. № 3-4. - C. 171-172.

2. Skin fragility syndrome in a cat with cholangiohepatitis and hepatic lipidosis / Daniel AG, Lucas SR, Júnior AR [and ath.] // J Feline Med Surg. 2010. - № 12(2). - Р. 5.

3. Болезни собак и кошек. Комплексная диагностика и терапия болезней собак и кошек : учеб. пособие / [Т. К. Донская Г. Г. Щербаков, Г. В. Полушин] ; под ред. С. В. Старченкова. СПб. : Спец. литература, 2006. - 655 с.

4. Внутрішні хвороби тварин [В. І. Левченко, І. П. Кондрахін, М. О. Судаков та ін.]; за ред. В. І. Левченка. - Біла Церква, 1999. - Ч. 1. $376 \mathrm{c}$.

5. Чандлер Э. А. Болезни кошек / Э. А. Чандлер, К. Дж Гакселл, Р. М. Гаскелл; пер. с англ. М.: АКВАРИУМ ЛТД. - 2002 - 696 с.

6. Griffin $B$. Feline hepatic lipidosis. Treatment and recommendations / Griffin B. - Compend Contin Educ. - 2000. - № 22 - P. 910-922.

7. Gary D. The Feline Patient / Gary D. Nors- шення якості шерсті, наявність свербіжу та лупи. Ожиріння є сприятливим фактором розвитку ліпідозу печінки.

2. Найбільш часто гепатоліпідоз реєструється у стерилізованих свійських котів віком від 7 до 10 років.

3. Найчастіше захворювання на гепатоліпідоз реєструється у свійських котів британської та європейської короткошерстої порід - у 31,9 та 29,8 \% випадків відповідно.

worthy, DVM, DABVP (Feline); [4th ed.], Blackwell Publishing Ltd. - 2011. - 1052 p.

8. Metabolic and hormonal alterations in cats with hepatic lipidosis / B. Brown, GE Mauldin, J Armstrong [and all] // J Vet Intern Med. - 2000. №14(1) - P. 6.

9. Кирк Р. Современный курс ветеринарной медицины Кирка / Р. Кирк, Д. Бонагура.; [пер. с англ.] - М. : ООО «Аквариум принт». - 2005. $1376 \mathrm{c}$.

10. Center S.A., Crawford M.A., Guida L., Erb H. N., King $J$. A retrospective study of 77 cats with severe hepatic lipidosis: 1975-1990 // J. Vet. Intern. Med.1993. - № 7. - Р. 349-359.

11. Тилли Л. Болезни кошек и собак / Л. Тилли, Ф. Смит: пер. с англ. - М. : ГЭОТАР-МЕД, 2001. $-784 \mathrm{c}$.

12. Biourge V. C., Groff J. M., Munn R. J., Kirk C. A., Nyland T. G., Madeiros V. A., Morris J. G., Rogers Q. R. Experimental induction of hepatic lipidosis in cats. // Am. J. Vet. Res. - 1994, №55. - P. 12911302. 